\title{
Analisa Laju Sedimentasi di Dermaga 4 Pelabuhan Cigading 1 Provinsi Banten
}

\author{
Anisa Nabila ${ }^{1 *}$, Jarot Marwoto ${ }^{1}$, Petrus Subardjo ${ }^{1,}$ Azis Rifai ${ }^{1}$ dan Warsito Atmodjo ${ }^{1}$ \\ ${ }^{1}$ Departemen Oseanografi, Fakultas Perikanan dan Ilmu Kelautan, Universitas Diponegoro \\ Jl. Prof. H. Soedharto, SH,Tembalan, Kota Semarang, Kode Pos 50275 \\ *Email: ansnabila89@gmail.com
}

\begin{abstract}
Abstrak
Dermaga 4 Pelabuhan Cigading 1 mengalami perubahan kedalamanyang diakibatkan oleh adanya sedimentasi apabila tidak ditindaklanjuti hal ini dapat mengganggu aktifitas kapal pada dermaga 4. Tujuan dari penelitian ini untuk mengetahui nilai laju sedimentasi yang terjadi di dermaga 4. Penelitian ini dilaksanakan pada tanggal 1 Januari 2020 - 30 Januari 2020. Metode penelitian yang digunakan yaitu metode kuantitatif dengan pengambilan sampel sedimen untuk analisa ukuran butir sedimen dan nilai laju sedimentasi. Selain itu, data arus pasang surut dan debit sungai diperlukan untuk mengetahui pergerakan sedimen, sedangkan data batimetri digunakan untuk membandingkan perbedaan kedalaman antara tahun 2020 dengan tahun 2018. Hasil dari penelitian menunjukkan bahwa sedimentasi terkecil terjadi pada stasiun 2 yang terletak di dekat laut yaitu sebesar $0.0789 \mathrm{gr} / \mathrm{cm}^{2} / \mathrm{hari}$ sedangkan nilai terbesar terdapat pada stasiun 6 yang terletak di muara sungai sebesar $2.7479 \mathrm{gr} / \mathrm{cm}^{2} / \mathrm{hari}$. Hal ini membuat kedalaman dermaga mengalami perubahan kedalaman dalam kurun waktu 2 tahun. Berdasarkan hasil penelitian dapat disimpulkan bahwa laju sedimentasi di daerah ini berasal dari Sungai Citayur.
\end{abstract}

Kata kunci: Laju Sedimentasi, Arus Pasang Surut, Debit Sungai, Pelabuhan Cigading 1

\begin{abstract}
Sedimentation occurring around Jetty 4 Cigading 1 Harbor. It can be impact to ships activity in the harbor and can be serious thing when we are ignoring this problem. The aim of this research is to discover the value of sedimentation rate. This research was done on January $1^{\text {st }}-30^{\text {th }}$, 2020. The method used in this research is quantitative with took the sample of sediment for grain size analys and sedimentation rate analys. Other than that, data that usedin this research are tidal current and river regime needed to know for the movement of sediment. Bathimetry used to compare at least 2 years from 2018 to 2020 to know transformation of depth. The result of research shows that the smallest sedimentation happen in the station 2 that's near the seas about $0.0789 \mathrm{gr} / \mathrm{cm}^{2} /$ day while the biggest sedimentation happen in station 6 that was in estuary about $2.7479 \mathrm{gr} / \mathrm{cm}^{2} /$ day. That's made the depth of the port had a sedimentation in 2 years. Based on the research conclude that this area has been shallowing caused by sedimentation that from Citayur River.
\end{abstract}

Keywords: Sedimentation Rate, Tidal Current, River Regime, Cigading 1 Harbor

\section{PENDAHULUAN}

Pelabuhan Cigading merupakan pelabuhan barang yang berada di Kawasan Krakatau Steel tepatnya di Kota Cilegon, Provinsi Banten. Pelabuhan ini dikelola oleh PT. Krakatau Bandar Samudera. Pelabuhan ini melayani berbagai jenis kapal dalam kategori Bulk Cargoes. Barang yang biasa di bawa yaitu kedelai, jagung, gisum, garam, pupuk dan gula merahbaik dari dalam negeri (eksport) ataupun dari luar negeri (import).Dermaga 4 merupakan salah satu dermaga di Pelabuhan Cigading 1 dengan kapasitas kapal 10.000 DWT. Letak dermaga ini berada di dalam kolam pelabuhan yang terlindungi oleh jetty dermaga lainnya (PT. Krakatau Bandar Samudera, 2014).

Lokasi dermaga 4 dekat dengan aliran Sungai Citayur yang berasal dari darat menuju ke kolam pelabuhan dermaga 4 ke arah laut perairan Selat Sunda. Perairan Selat Sunda merupakan lokasi pertemuan antara Laut Jawa dengan Samudera Hindia. Perairan Laut Jawa dengan Perairan Samudera Hindia memiliki karakteristik yang berbeda sehingga pertemuan antara keduanya akan mempengaruhi kondisi oseanografi di Selat Sunda (Amri et al., 2007). 
Letak dan kondisi geografis daerah ini menyebabkan beberapa permasalahan di sekitar daerah Dermaga 4, Pelabuhan Cigading 1. Salah satunya yaitu sedimentasi (PT. Krakatau Bandar Samudera, 2014). Berdasarkan wawancara dengan nelayan sekitar, Sungai Citayur merupakan akses kapal nelayan dari darat menuju ke laut. Disaat musim hujan sering mengalami pengendapan sediemntasi yang dikarenakan banjir bandang yang terjadi. Hal ini juga dapat berpengaruh terhadap kolam pelabuhan dermaga 4, sedimentasi tidak hanya terjadi di Sungai Citayur tetapi juga di muara sungai yang berhubungan langsung dengan kolam pelabuhan.

Penelitian mengenai laju sedimentasi ini belum pernah dilakukan di Dermaga 4, Pelabuhan Cigading 1. Maka dari itu perlu dilakukan kajian terhadap laju sedimentasi untuk mengetahui perubahan batimetri di daerah tersebut. Hal ini akan sangat berpengaruh terhadap optimalisasi fungsi kolam pelabuhan.

\section{MATERI DAN METODE}

Materi penelitian yang digunakan meliputi pasang surut, arus laut, batimetri tahun 2018 dan 2020, debit sungai dan sampel sedimen. Penelitian dilakukan pada bulan Januari 2020 hingga bulan Agustus 2020 yang meliputi pengukuran dan pengambilan sampel di lapangan, pengolahan data di laboratorium, analisis data hasil penelitian dan penyusunan laporan penelitian. Lokasi penelitian secara geografis terletak pada koordinat $6^{\circ} 0^{\prime} 34.11^{\prime \prime}-6^{\circ} 1^{\prime} 16.68^{\prime \prime}$ Lintang Selatan dan $105^{\circ} 57^{\prime} 0.75^{\prime \prime}-105^{\circ} 57^{\prime} 42.99^{\prime \prime}$ Bujur Timur. Peta penelitian ditunjukan pada Gambar 1.

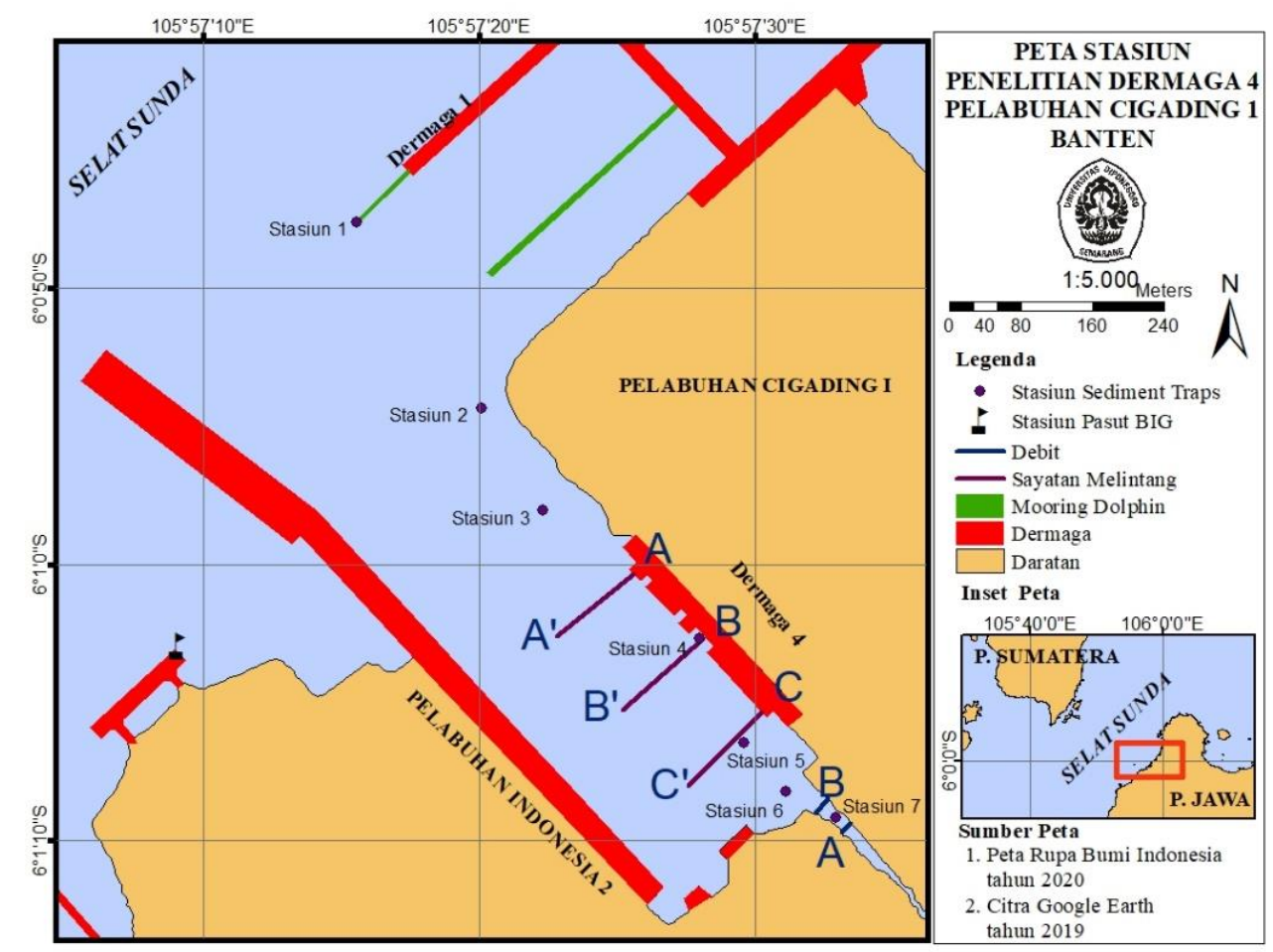

Gambar 1.Peta Lokasi Penelitian

Penelitian ini menggunakan metode kuantitatif yaitu metode yang memenuhi kaidah-kaidah ilmiah dengan data penelitian berupa angka-angka dan analisis menggunakan statistik atau model (Sugiyono, 2009). Penentuan titik lokasi pengambilan sampel sedimen menggunakan metode purposive sampling yaitu pengambilan sampel pada beberapa titik yang mewakili keadaan keseluruhan wilayah yang dikaji (Hadi dan sutrisno, 1982). Penentuan titik lokasi ini dibagi menjadi beberapa luasan area yang mewakili Sungai Citayur, Kolam Dermaga 4 dan laut dengan jumlah 7 titik lokasi penempatan sediment trap. 


\section{Arus}

Pengukuran arus menggunakan metode lagrange dengan mengikuti pergerakan partikel air laut yang digerakkan oleh arus. Pengukuran dilakukan dengan menggunakan bola duga dan alat penentu arah yaitu kompas tembak. Pegukuran arus dilakukan dengan pendekatan waktu selama 2 menit. Pengukuran ini dilakukan dua kali saat terjadi pasang dan dua kali saat terjadi surut di 3 titik lokasi yang mewakili keseluruhan lokasi penelitian. Pengolahan data arus dapat dilakukan dengan Flow Model Flexible Mesh pada software MIKE 21. Pengolahan arus pada software ini dapat memodelkan pola pergerakan arus berupa kecepatan dan arah arus didaerah penilitian.

\section{Debit Sungai}

Pengambilan data debit sungai dilakukan dengan mengukur lebar sungai dan kecepatan aliran. Pengukuran ini dilakukan dengan pengukuran kedalaman yang dibagi menjadi 3 sub penampang. Hasil pengambilan data di lapangan digunakan untuk mendapatkan nilai luas sub penampang basah dan kecepatan rata rata di setiap sub penampang hingga mendapatkan debit rata-rata sub penampang yang akhirnya disebut sebagai debit total penampang. Perhitungan debit dapat menggunakan rumus Mid Section Method.

\section{Pasang Surut}

Data pasang surut diunduh melalui website resmi Badan Informasi Geospasial (http://inasealevelmonitoring.big.go.id/ipasut/data/map) di Stasiun Pengamatan Pelabuhan Ciwandan, Banten dengan titik koordinat $105^{\circ} 57^{\prime} 8,95^{\prime \prime} \mathrm{E}-6^{\circ} 1{ }^{\prime} 3,14^{\prime}$ 'S . Data pasang surut diunduh selama satu bulan pada tanggal 1 - 31 Januari 2020. Metode yang digunakan yaitu metode admiralty dengan menghitung konstanta pasang surut harmonik dari pengamatan ketinggian air laut tiap jam selama 29 piantan (29 hari). Metode ini digunakan untuk menentukan komponen-komponen pasang surut dan tipe pasang surut.

\section{Batimetri}

Pengukuran data batimetri dilakukan dengan metode akustik yaitu echosounder singlebeam. Pengukuran batimetri dilakukan dengan menggunakan pendekatan waktu. Pengukuran data batimetri dilakukan dengan mengikuti alur perum yang telah dirancang sebelumnya. Hasil lapangan akan dikoreksi dengan nilai pasang surut. Pengukuran reduksi oleh pasang surut dapat dirumuskan sebagai berikut (Soeprapto,2001):

$$
\mathrm{Rt}=\mathrm{TWLt}-(\mathrm{MSL}+\mathrm{Zo})
$$

Keterangan :

Rt : besarnya nilai reduksi yamg diberikan kepada hasil pengukuran Kedalaman pada waktu t;

TWLt : kedudukan permukaan air sebenarnya pada waktu t;

MSL : muka air laut rata-rata; dan

Zo : kedalaman muka air surutan dibawah MSL.

Setelah itu dapat dihitung kedalaman sebenarnya dengan rumus sebagai berikut :

$\mathrm{D}=\mathrm{dT}-\mathrm{Rt}$

Keterangan :

D : kedalaman sebenarnya;

dT : kedalaman terkoreksi tranducer; dan

Rt : besarnya nilai reduksi yamg diberikan kepada hasil pengukuran kedalaman pada waktu t.

\section{Laju Sedimentasi}

Pengambilan sampel sedimen menggunakan sediment trap yang diletakkan di dasar peraiaran dengan titik yang telah ditentukan. Sediment trap ini berbentuk silinder berupa pipa paralon dengan diameter 4 inch dan tinggi $50 \mathrm{~cm}$. Pengambilan sampel sedimen ini dilakukan dengan interval 7 hari sekali setelah penempatan sediment trap (dilakukan 3 kali pengambilan sampel) selama 21 hari. Total 
sampel sedimen yang diperoleh yaitu 21 sampel yang aka diolah di laboratorium dan dianalisa untuk mengetahui laju sedimentasinya.

Laju sedimentasi dapat ditentukan dengan menggunakan metode Buchanan (1984) dalam Holme dan McIntyre (1984). Tahapan yang dilakukan dalam pengolahan sampel sedimen yaitu:

1. Sampel sedimen yang sudah dikeringkan ditimbang sebanyak 100 gram.

2. Sampel sedimen yang sudah ditimbang diayak menggunakan sieve shaker dengan saringan berukuran $2 \mathrm{~mm}, 0,5 \mathrm{~mm}, 0,312 \mathrm{~mm}, 0,125 \mathrm{~mm}$, dan 0,063 $\mathrm{mm}$. Pengayakan dilakukan selama 10 menit.

3. Pisahkan sampel sedimen masing masing ukuran dengan menggunakan plastik yang telah ditimbang terlebih dahulu, lalu timbang kembali berat plastik yang telah dimasukkan sampel sedimen.

4. Sampel sedimen yang lolos saringan ukuran $0,063 \mathrm{~mm}$ dari sieve shaker dipindahkan dalam gelas ukur volume $1000 \mathrm{ml}$ yang sudah berisi aquades, lalu diaduk secara homogen kemudian dilakukan pemipetan sesuai dengan waktu pemipetan yang dapat dilihat pada Tabel 3.

Tabel 1. Jarak Tenggelam dan Waktu Pemipetan

\begin{tabular}{cccc}
\hline No & $\begin{array}{c}\text { Waktu } \\
(\text { Jam Menit Detik) }\end{array}$ & Jarak Tenggelam $(\mathrm{cm})$ & Diameter $(\mathrm{cm})$ \\
\hline 1. & 000058 & 20 & 0,0625 \\
2. & 000156 & 10 & 0,0312 \\
3. & 000744 & 10 & 0,0156 \\
4. & 003100 & 10 & 0,0078 \\
5. & 020300 & 10 & 0,0039 \\
\hline
\end{tabular}

(Sumber : Buchanan (1984) dalam Holme dan McIntyre (1984))

5. Pemipetan dilakukan dengan cara mengambil larutan sedimen dengan pipet volume sebanyak $10 \mathrm{ml}$, kemudian dituang ke dalam botol percontohan yang ditimbang sebelumnya.

6. Terhadap hasil pemipetan setiap ukuran butir $0,0625 \mathrm{~mm}, 0,0312 \mathrm{~mm}, 0,0156 \mathrm{~mm}, 0,0078 \mathrm{~mm}$, dan $0,0039 \mathrm{~mm}$ dilakukan penimbangan berat sedimen yang telah dipipeting untuk menghitung berat bersih dari sedimen tersebut.

7. Hasil pengayakan dan pemipetan selanjutnya digunakan untuk penentuan jenis sedimen di tiap lokasi berdasarkan sistem persamaan segitiga Shepard.

8. Kemudian hasil pemipetan masing-masing diameter dilakukan penyaringan menggunakan kertas saring milipore $0,45 \mu \mathrm{m}$, yang sebelumnya sudah dibasahi dengan aquades. Hasil tersebut dikeringkan menggunakan oven pada suhu $105^{\circ} \mathrm{C}$ selama 5 menit dan kemudian ditimbang. Penyaringan dilakukan dengan pompa hisap (vacum pump).

9. Hasil dari penyaringan kemudian di oven selama 5 menit pada suhu $105^{\circ} \mathrm{C}$.

10. Sampel sedimen serta kertas saring yang sudah kering lalu ditimbang.

Perhitungan laju sedimentasi menggunakan rumus APHA (1976) dalam Supriharyono (1990), yaitu:

Laju sedimentasi $=\mathrm{A}-\mathrm{B} /$ luas $/$ minggu ( $\mathrm{gr} /$ luas paralon $/ \mathrm{ming} g)$

$$
=\frac{1000}{\pi \cdot r^{2}} \quad(A-B)\left(g r / m^{2} / \text { hari }\right)
$$

Keterangan:

A: Berat alumunium foil + sedimen setelah pemanasan $105^{\circ} \mathrm{C}$ dalam gram

$\mathrm{B}$ : Berat awal alumunium foil setelah pemanasan $105^{\circ} \mathrm{C}$ dalam gram

\section{HASIL}

Arus

Gambar 2 merupakan hasil olahan model arus. Pukul 14:00 pada tanggal 21- 22 Januari 2020 merupakan kondisi arus laut saat surut menuju pasang. Sedangkan pada tanggal yang sama di jam 01:00 terjadi kondisi arus laut saat pasang menuju surut. Hasil pada kondisi arus saat surut menuju pasang di muara sungai akan memiliki arah arus menuju ke dalam sungai, 
sedangkan saat pasang menuju surut arus akan mengarah ke luar sungai menuju kolam pelabuhan.

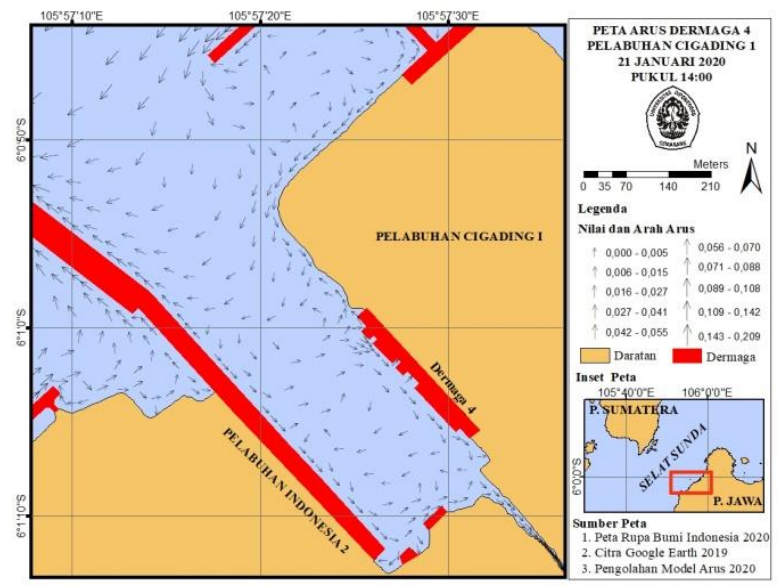

(A)

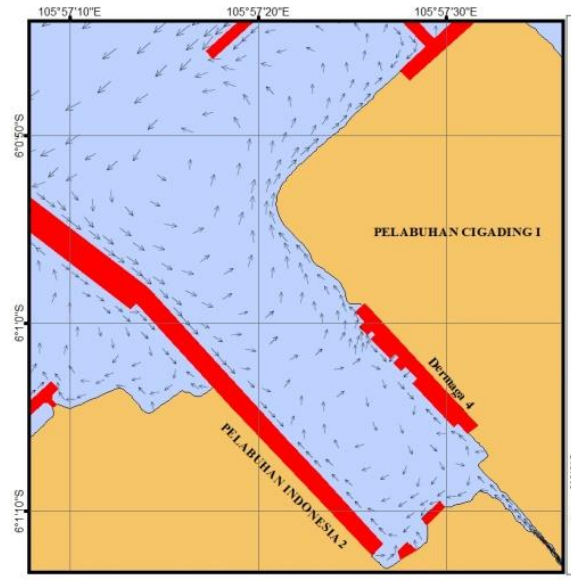

(C)
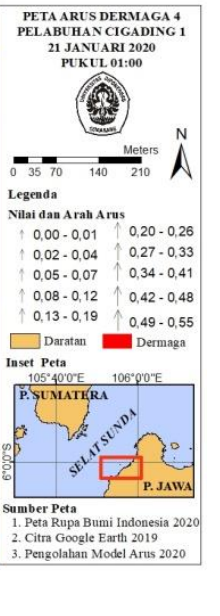

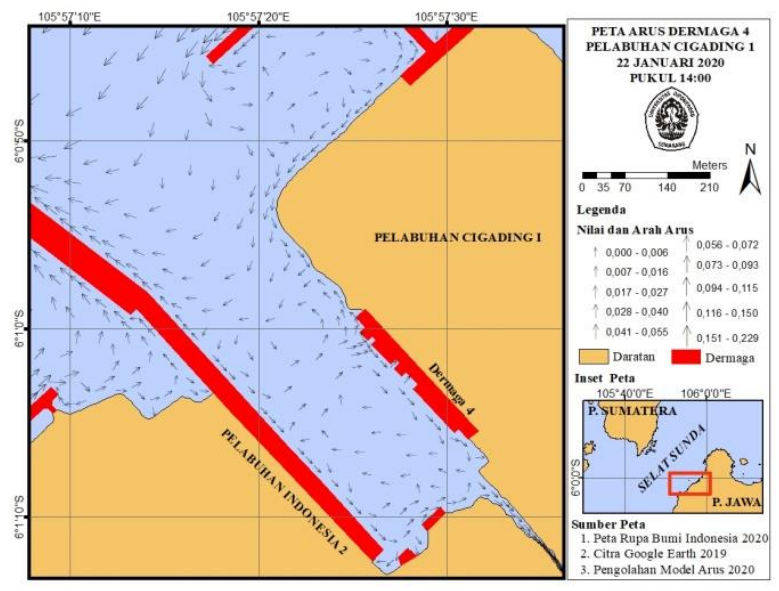

(B)

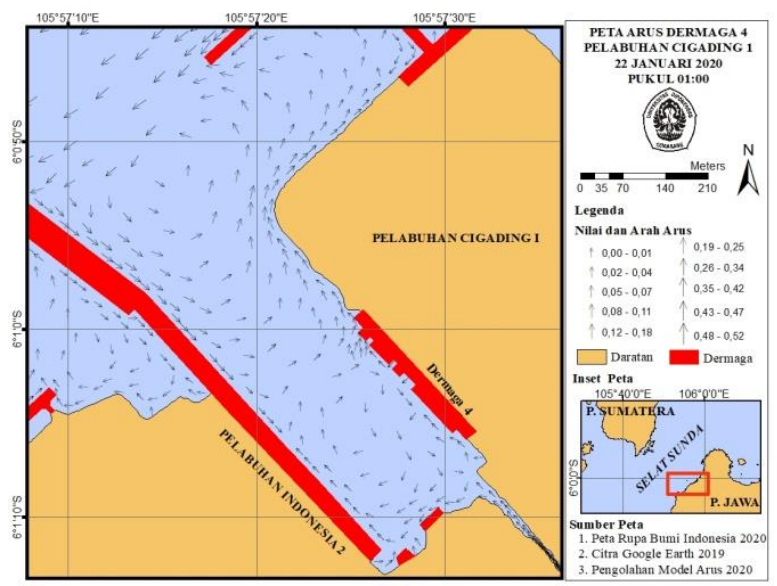

(ע)

Gambar 2. Model Arus 21 Januari 2020 pukul 14:00 (A), 22 Januari 2020 pukul 14:00 (B), 21 Januari 2020 pukul 01:00 (C), dan 22 Januari 2020 pukul 01:00 (D)

\section{Debit Sungai}

Berdasarkan perhitungan debit sungai Citayur di dekat Dermaga 4 Pelabuhan Cigading 1, didapatkan nilai aliran debit penampang A yaitu sebesar $0.099 \mathrm{~m}^{3} / \mathrm{s}$ dan rata-rata aliran debit sebesar $0.033 \mathrm{~m}^{3} / \mathrm{s}$. Sedangkan pada penampang B nilai aliran debit sebesar $0.032 \mathrm{~m}^{3} / \mathrm{s}$ dan nilai rata-rata debit sebesar $0.011 \mathrm{~m}^{3} / \mathrm{s}$ yang ditunjukkan Tabel 2 .

\section{Pasang Surut}

Nilai formzhal yang didapat sebesar 0.5403 sehingga dapat diketahui tipe pasang surut di lokasi pengamatan yaitu pasang surut Campuran Condong ke Harian Ganda. Berdasarkan nilai elevasi pasang surut diatas dapat dilihat bahwa nilai Mean Sea Level (MSL) yaitu $121 \mathrm{~cm}$ sedangkan nilai Highest High Water Level (HHWL) yaitu $184 \mathrm{~cm}$ dan nilai Lowest Low Water Lever (LLWL) yaitu $59 \mathrm{~cm}$. Grafik pasang surut bulan Januari 2020 dapat dilihat pada Gambar 3. 
Tabel 2.Hasil Debit Penampang A (A) dan Penampang B (B)

\begin{tabular}{|c|c|c|c|c|}
\hline Titik & $\begin{array}{l}\text { Luas Penampang Basah } \\
\qquad\left(\mathrm{m}^{2}\right)\end{array}$ & $\begin{array}{c}\text { Kedalaman } \\
(\mathrm{m})\end{array}$ & $\begin{array}{c}\text { Kecepatan } \\
(\mathrm{m} / \mathrm{s})\end{array}$ & Debit $\left(\mathrm{m}^{3} / \mathrm{s}\right)$ \\
\hline 1 & 1.301 & 0.63 & 0.005 & 0.007 \\
\hline 2 & 5.885 & 0.95 & 0.005 & 0.029 \\
\hline 3 & 12.706 & 1.23 & 0.005 & 0.064 \\
\hline \multirow{2}{*}{\multicolumn{4}{|c|}{$\begin{array}{c}\text { Jumlah } \\
\text { Rata-rata }\end{array}$}} & 0.099 \\
\hline & & & & 0.033 \\
\hline \multicolumn{5}{|c|}{$(\mathrm{A})$} \\
\hline Titik & $\begin{array}{l}\text { Luas Penampang Basah } \\
\qquad\left(\mathrm{m}^{2}\right)\end{array}$ & $\begin{array}{l}\text { Kedalaman } \\
(\mathrm{m})\end{array}$ & $\begin{array}{l}\text { Kecepatan } \\
(\mathrm{m} / \mathrm{s})\end{array}$ & Debit $\left(\mathrm{m}^{3} / \mathrm{s}\right)$ \\
\hline 1 & 1.363 & 0.5 & 0.001 & 0.001 \\
\hline 2 & 10.219 & 1.25 & 0.001 & 0.010 \\
\hline 3 & 20.885 & 1.53 & 0.001 & 0.021 \\
\hline \multicolumn{4}{|c|}{ Jumlah } & 0.032 \\
\hline \multicolumn{4}{|c|}{ Rata-rata } & 0.011 \\
\hline
\end{tabular}

(B)

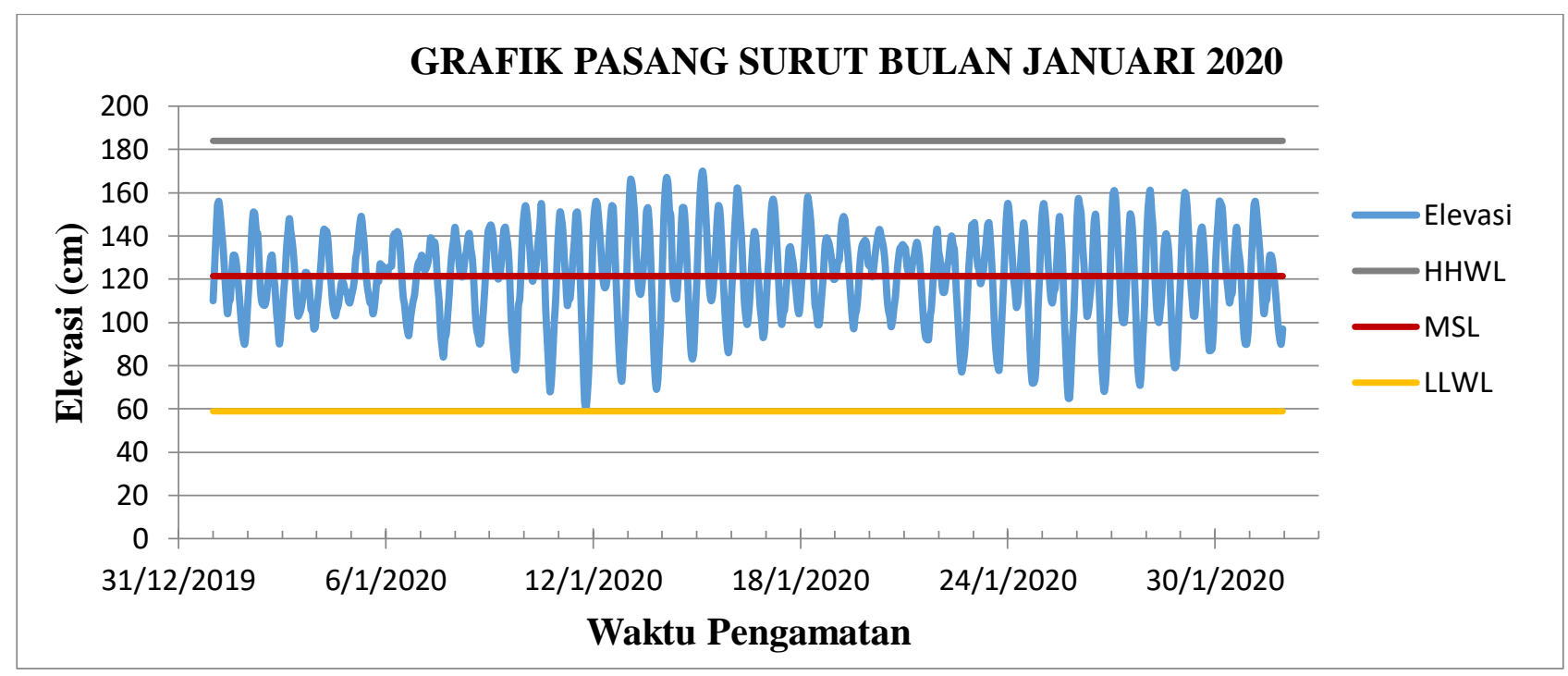

Gambar 3. Grafik Pasang Surut.

\section{Batimetri}

Dari hasil pemeruman batimetri data yang pertama kali diperoleh yaitu waktu pemeruman, kedalaman yang terbaca oleh echosounder, arah dan posisi titik perum. Data hasil pemeruman harus dilakukan koreksi terhadap letak kedalaman transducer dan koreksi nilai Mean Sea Level (MSL) air laut. Data batimetri tahun 2020 di daerah depan Dermaga 4 memiliki kedalaman hingga $11 \mathrm{~m}$, sedangkan tahun 2018 mencapai 13 m yang ditunjukkan Gambar 4.

\section{Laju Sedimentasi}

Berdasarkan hasil perhitungan laju sedimentasi pada tiap stasiun didapatkan hasil laju sedimentasi terbesar terjadi pada stasiun 6 pengambilan sampel ketiga yaitu sebesar $2.0530 \mathrm{gr} / \mathrm{cm}^{2} / \mathrm{hari}$. Sedangkan untuk nilai laju sedimentasi terendah terdapat pada stasiun 2 pengambilan sampel kedua dengan besar nilai $0.0798 \mathrm{gr} / \mathrm{cm}^{2} /$ hari. Hasil nilai laju sedimentasi pada setiap stasiun dalam bentuk grafik dapat dilihat pada Tabel 3. 

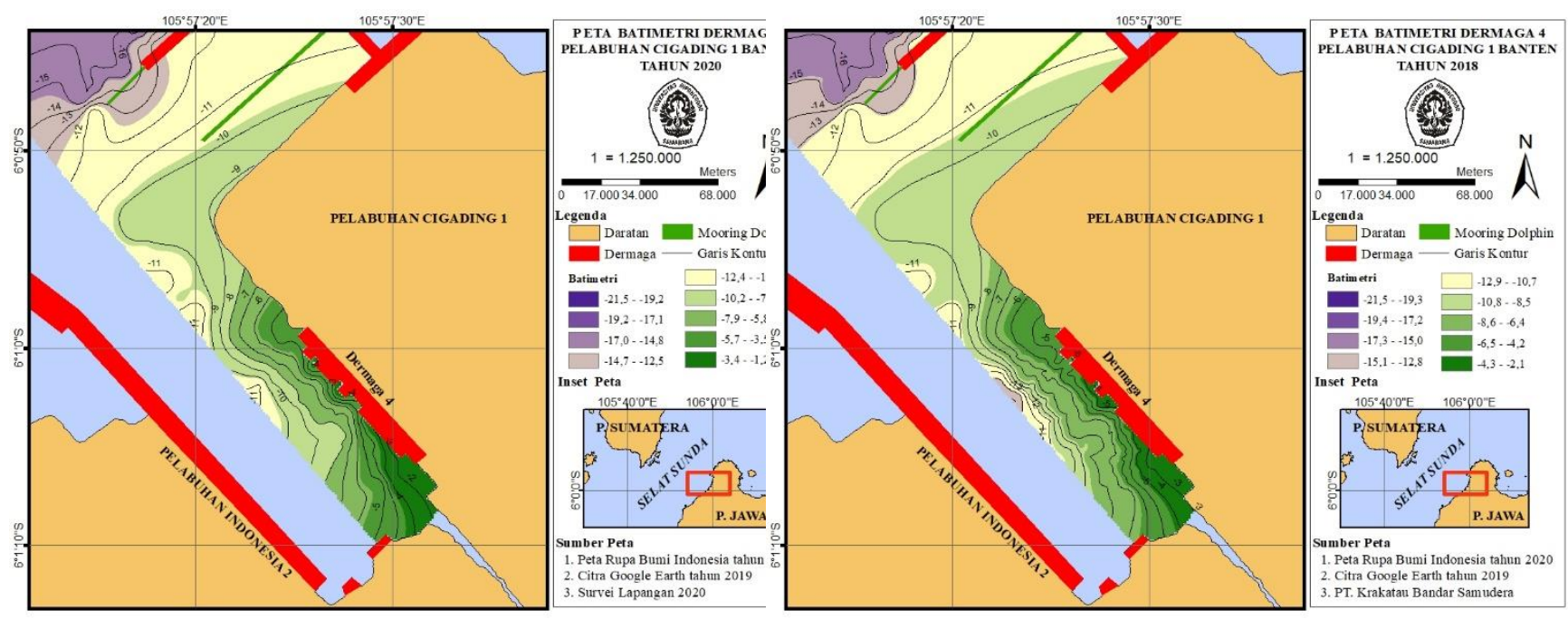

Gambar 4. Peta Batimetri tahun 2020 (kanan) dan peta batimetri tahun 2018 (kiri)

Tabel 3. Hasil Laju Sedimentasi

\begin{tabular}{cccc}
\hline & \multicolumn{3}{c}{ Tanggal } \\
\cline { 2 - 4 } Stasiun & $9 / 01 / 2020-$ & $9 / 01 / 2020-$ & $9 / 01 / 2020-$ \\
& $16 / 01 / 2020$ & $23 / 01 / 2020$ & $30 / 01 / 2020$ \\
\hline 1 & 0.2119 & 0.1705 & 0.2191 \\
2 & 0.0879 & 0.0798 & 0.0814 \\
3 & 0.1278 & 0.1219 & 0.1297 \\
4 & 0.1944 & 0.1801 & 0.1256 \\
5 & 0.1509 & 0.2177 & 1.4072 \\
6 & 2.3154 & 2.1874 & 2.7479 \\
7 & 1.5155 & 2.2711 & 2.0530 \\
\hline
\end{tabular}

\section{PEMBAHASAN}

Pergerakan arus laut dan debit sungai dapat mempengaruhi faktor lain salah satunya yaitu sedimen. Partikel sedimen di dasar laut maupun di sungai dapat terbawa oleh aliran air mengikuti arah pergerakan arus laut maupun debit sungai. Partikel sedimen yang terbawa oleh air laut maupun air sungai sangat bergantung pada besar kecepatan aliran, semakin besar nilai kecepatan aliran maka semakin banyak dan semakin besar ukuran partikel sedimen yang dapat terbawa oleh aliran. Namun bila nilai kecepatan aliran semakin kecil maka partikel sedimen yang dibawa semain sedikit dan ukuran butir partikel semakin kecil ataupun partikel sedimen tersebut dapat terendakan di dasar perairan.

Menurut Anasiru (2005), muara merupakan titik pertemuan antara aliran sungai dengan arus laut. Arus laut saat pasang terjadi pertemuan aliran sungai yang menuju ke laut dengan air pasang dari laut di muara sungai, pergerakan keduanya akan bertemu di muara sungai dengan arah pergerakan air yang berlawanan. Hal ini menyebabkan mengecilkan kecepatan aliran di muara sungai sehingga partikel sedimen yang di bawa aliran sungai dan arus pasang mengendap di muara sungai. Keadaan ini berbeda pada saat air laut sedang surut, debit sungai yang mengarah ke laut akan bertemu dengan aliran laut dengan kondisi surut sehingga keduanya akan mengalir bersama ke arah laut.

Dilihat pada table 3, nilai laju sedimentasi di stasiun 6 paling tinggi dibandingkan dengan stasiun lainnya. Hal ini dikarenakan letak stasiun ini tepat berada di muara sungai yaitu tempat bertemunya arus pasang surut laut dengan aliran sungai sehingga menyebabkan penumpukan sedimentasi baik dari laut maupun dari sungai. Hal ini menyebabkan terjadinya perubahan kedalaman di sekitar muara sungai. 
Dari gambar 4,, pada tahun 2020 terlihat adanya perubahan kedalaman jika dibandingkan dengan kedalaman tahun 2018. Pada bagian kolam pelabuhan depan dermaga 4 terlihat bahwa kedalaman maksimal yaitu $11 \mathrm{~m}$ sedangkan pada tahun 2018 kedalaman maksimal di depan dermaga 4 yaitu $14 \mathrm{~m}$. selain itu perbedaan kontur juga terlihat jelas di depan sungai Citayur, pada tahun 2020 kedalaman depan sungai citayur berkisar antara $5 \mathrm{~m}$ hingga $2 \mathrm{~m}$ sedangkan pada tahun 2018 kedalamannya yaitu $6 \mathrm{~m}$ hingga $3 \mathrm{~m}$. Hal ini dapat dikarenakan nilai laju sedimentasi di depan sungai lebih tinggi dibandingkan dengan stasiun lainnya sehingga menyebabkan adanya perubahan kedalaman menjadi dangkal.

\section{KESIMPULAN}

Berdasarkan hasil dari penelitian ini dapat disimpulkan bahwa, nilai laju sedimentasi yang terjadi yaitu antara $0.0798 \mathrm{gr} / \mathrm{cm}^{2} /$ hari hingga $2,7479 \mathrm{gr} / \mathrm{cm}^{2} /$ hari. Nilai laju sedimentasi terkecil terdapat pada stasiun 2 periode ke- 2 sedangkan nilai laju sedimentasi terbesar terdapat di stasiun 6 periode ke- 3 yang terletak di muara sungai Citayur.

\section{DAFTAR PUSTAKA}

Amri Khairul, Manurung Djisman, Vincentius P. Siregar. 2007. Dinamika Kondisi Oseanografi Musiman Perairan Selat Sunda Dari Analisis Data Multitemporal, Jurnal Penelitian Perikanan Indonesia 13(3) : 191 - 199

Anasiru Triyanti. 2005. Analisi Perubahan Kecepatan Aliran Pada Muara Sungai Palu. Jurnal SMARTek, 3 (2) : 101 - 112

Buchanan, J. B. 1984. Sediment analysis. in N. A. Holme, \& A. D. McIntyre (Eds.), Methods for the Study of Marine Benthos. 1nternational Biological Programme. 2nd ed. Oxford: Blackwell Scientifc Publications., 41-65 pp.

Hadi, Sutrisno. 1982. Metodologi Reseach, Jilid I. Yogyakarta : YP. Fakultas Psikologi, UGM.

PT. Krakatau Bandar Samudera. 2014. Sekilas KBS. https://cigadingport.com/id/sekilas-kbs (10 September 2020).

Soeprapto. 2001. Survei Hidrografi. Gadjah Mada University Press, Yogyakarta.

Sugiyono. 2009. Metode Penelitian Bisnis (Pendekatan Kuantitatif, Kualitatif, dan R\&D). Alfabeta, Bandung.

Supriharyono. 1990. Hubungan Tingat Sedimentasi dengan Hewan Makrobentos di Perairan Muara Sungai Moro Demak Kab. Dati II Jepara. Lembaga Penelitian Universitas Diponegoro, Semarang. 